\title{
Methods of measurement of milk yield and composition in nursing mares : a review
}

\author{
M. Doreau and S. Boulot \\ INRA, Laboratoire de la Lactation, Theix, 63122 Ceyrat, France
}

(received 17 March 1988, accepted 23 December 1988)

\begin{abstract}
Summary - This review describes and analyses the most commonly used methods of estimating milk yield of nursing mares : milking without or with oxytocin injection, weighing the foal before and after suckling, dilution of labelled water in foal body water : milking only does not appear to constitute an accurate method. Weighing before and after suckling requires numerous measurements, due to the foal's frequent sucks. Foal body water dilution does not disturb the mother-offspring relationships, but can only be used when milk is the sole water source for the foal.

Conditions of sampling and analysis for milk composition in nursing mares are described; incomplete milking (without oxytocin injection) involves a bias regarding milk fat content because milking is unusual. An oxytocin injection allows evaluation of the composition of secreted milk. The period of mare-foal separation should be short and close to the natural interval between sucks. Milk analysis should take into account the composition of mare milk fat and protein; infrared spectrophotometry should be calibrated for mare's milk.

Some of the differences in the literature on milk secretion data can probably be explained by the methods of measurement of milk yield and composition.
\end{abstract}

mare - milk yield - milk composition - methods of measurement

Résumé - Méthodes de mesure de la production et de la composition du lait chez la jument allaitante : revue bibliographique. Dans une première partie, cette revue analyse les principales méthodes d'estimation de la production laitière des juments allaitantes : traite sans ou avec injection d'ocytocine, pesée du poulain avant et après tétée, dilution d'eau marquée dans l'eau corporelle du poulain. Seule la traite semble être une méthode imprécise. La pesée avant et après tétées nécessite des mesures nombreuses, en raison de la fréquence élevée des tétées du poulain. La dilution de l'eau corporelle du poulain ne perturbe pas le comportement normal mèrejeune, mais cette technique ne peut être utilisée que lorsque le lait est la seule source d'eau pour le poulain.

Dans une deuxième partie, les conditions d'échantillonnage et d'analyse de la composition du lait des juments allaitantes sont décrites. Une traite incomplète (sans injection d'ocytocine) entraine un biais sur la détermination du taux butyreux, les juments n'étant pas habituées à la traite. L'injection d'ocytocine permet d'estimer la composition du lait sécrété. La séparation entre la jument et le poulain doit être de courte durée et proche de l'intervalle naturel entre tétées. L'analyse du lait doit prendre en compte la composition des matières grasses et des protéines du lait de jument, de sorte que les méthodes de spectrophotométrie dans l'infrarouge doivent être calibrées pour le lait de jument. 
En conclusion, une partie des différences de niveau de production ou de composition entre auteurs peut être expliquée par le choix des méthodes de mesure.

Jument - production laitière - composition du lait - méthodes de mesure

\section{Introduction}

The optimal feeding of mares involves the knowledge of their requirements, especially for milk production. These are easy to measure in dairy females, but must be estimated in nursing mares, which constitute the main proportion of herds in most countries, with the exception of the USSR and Mongolia. The main methodological problems are the determination of the effective yield of milk consumed by the foal, and the representative sampling of milk. A literature survey shows high variations in milk yield $(2-3.5 \mathrm{~kg}$ per $100 \mathrm{~kg}$ live weight; Doreau and Boulot, 1989), and in milk composition (for example, extreme reported values of fat content are 0 and $7.9 \%$; Neuhaus, 1959). A proportion of these high and often unexplained variations in mare milk yield and/or composition from one trial to another may be a result of the various measurement techniques. The purpose of the present paper is to critically evaluate the methods of estimating milk production in nursing mares, in order to assess the reliability of the different experimental data, summarized in the reviews of Neseni et al. (1958), Neuhaus (1959) and Doreau and Boulot (1989).

\section{Methods of estimating milk yield}

Three types of method are used. The 2 most common are milking and foal weighing before and after suckling. A more recent method is that of diluting a marker in foal body water. Because of the lack of comparisons between these methods in the mare (except for Doreau et al., 1986a), their respective advantages and shortcomings will be analyzed with reference to observations made on other species, taking into account the physiological specificities of equids.

Several authors have estimated mare milk from foal growth, more often than not using relationships established in cattle (Leonhard, 1956). This method will not be described in the present paper as it is too indirect and provides only rough estimates, as shown in studies in which mare milk production, measured more accuratelv, was compared to foal growth (Bouwman and Van Der Schee, 1978; Doreau et al., 1986b). In particular, the relationship depends on the extent of maintenance requirements, thus on foal age.

\section{Mare milking (Table I)}

Mare milking is the oldest method of estimating milk yield in nursing mares. It was used as early as 1896 by Camerer and Soldner, quoted by Neuhaus (1959). These authors had obtained only low yields : $4.5 \mathrm{I}$ as a total of 5 milkings. This is not surprising because occasional milking of normally nursing females leads to an underestimation of milk yield, due to incomplete udder emptying. Such data have been shown in ewes (Ricordeau and Denamur, 1962) and cows (Le Neindre et al., 1976). The quantity of mare cisternal milk is low when compared to alveolar milk : less than half of the total yield 
Table I. Amount of milk obtained in one milking.

\begin{tabular}{|c|c|c|c|}
\hline References & Method of milking & $\begin{array}{l}\text { Amount of milk } \\
\qquad(\mathrm{ml})\end{array}$ & Experimental conditions \\
\hline \multicolumn{4}{|l|}{ Dairy mares } \\
\hline Alaguzhin (1964) & - & $1000-2000$ & at peak of lactation (34 mares) \\
\hline \multicolumn{4}{|l|}{$\begin{array}{l}\text { Cherepanova } \\
\text { and Belokobylenko }\end{array}$} \\
\hline (1974) & mechanical & $375-2000$ & extreme values \\
\hline \multicolumn{4}{|l|}{$\begin{array}{l}\text { Fedotov } \\
\text { and Duisembaev }\end{array}$} \\
\hline$(1974)$ & mechanical & $1200-1650$ & $\begin{array}{l}\text { means : comparison } \\
\text { of } 3 \text { breeds ( } 47 \text { mares) }\end{array}$ \\
\hline Cherepanova (1979) & mechanical & $<2200$ & data on 20 herds \\
\hline \multirow[t]{2}{*}{ Tarasevich (1979) } & mechanical & $1600-1800$ & $\begin{array}{l}\text { daily yield : } 13-14 \mathrm{~kg} \\
\text { (20 mares) }\end{array}$ \\
\hline & mechanical & $2300-3000$ & daily yield : $17-18 \mathrm{~kg}$ \\
\hline \multicolumn{4}{|l|}{ Nursing mares } \\
\hline Bilek et al. (1955) & mechanical & $300-1520$ & $\begin{array}{l}\text { 4th month of lactation } \\
\text { ( } 6 \text { mares) }\end{array}$ \\
\hline Neuhaus (1961) & manual with oxytocin & $<2000$ & - \\
\hline Ulirey et al. (1966) & manual & $152-324$ & $\begin{array}{l}4 \text { first months of lactation } \\
\text { (10 mares) }\end{array}$ \\
\hline Storch (1969) & mechanical & $2000-2500$ & - \\
\hline Johnston et al. (1970) & manual & $220-340$ & $\begin{array}{l}15 \text { first days of lactation } \\
\text { (6 mares) }\end{array}$ \\
\hline Oftedal et al. (1983) & manual with oxytocin & $1000 \pm 354$ & $\begin{array}{l}30 \text { min secretion for last suck } \\
2 \text { first months of lactation } \\
\text { ( } 5 \text { mares) } \\
1-2 \text { h secretion for last suck }\end{array}$ \\
\hline \multirow[t]{5}{*}{ Doreau et al. (1986a) } & manual with oxytocin & $265-1480$ & $\begin{array}{l}2 \text { days of lactation (10 mares) } \\
30 \text { min secretion for last suck }\end{array}$ \\
\hline & & $450-1760$ & $\begin{array}{l}9 \text { days of lactation ( } 10 \text { mares) } \\
40 \text { min secretion for last suck }\end{array}$ \\
\hline & & $405-1405$ & $\begin{array}{l}16 \text { days of lactation ( } 10 \text { mares) } \\
50 \text { min secretion for last suck }\end{array}$ \\
\hline & & $810-1650$ & $\begin{array}{l}1 \text { month of lactation (10 mares) } \\
60 \text { min secretion for last suck }\end{array}$ \\
\hline & & $925-2185$ & $\begin{array}{l}2 \text { months of lactation (10 mares) } \\
90 \text { min secretion for last suck }\end{array}$ \\
\hline
\end{tabular}

(Tumanova, 1966; Dyusembin, 1966; Le Du, 1986). This concept of "cisternal milk» should be improved in mares since Barone and Monnet (1955), by anatomical observations, assessed a $60-\mathrm{ml}$ content for cisterns of dry mares. In mares, no differences in oxytocin release have been shown between suckling and milking, as indirectly assessed by comparable values of blood concentration peaks (Dyusembin, 1972a; Sharma, 1974; Kuanyshbekova, 1975). However, the measurements were not carried out on the same breeds : dairy breeds for milked mares, saddle breed for nursing mares. The stimulus provided may not be as great in occasional 
milkings carried out with mares that are usually nursing. Moreover, the differences in experimental conditions and methods of oxytocin analysis do not allow the conclusion to be made that the physiological efficiency of milk ejection is the same for milking and suckling. Whether the foal is present or not during milking also appears important; Cherepanova and Belokobylenko (1974) noted that $20 \%$ of milked mares withheld their milk when their foal was at a distance from them.

The presence of the foal is not sufficient. Ashcraft and Tyznik (1976) milked one side of the udder while the foal suckled the other. They obtained low daily yields (minimum : $1.5 \mathrm{~kg}$ ). As milking takes longer than suckling, the rapid decrease in blood oxytocin may not have allowed the complete emptying of acini at the end of milking. Neuhaus (1961) observed that when one side was entirely milked before the other, $35 \%$ less milk was obtained from the second side than from the first side.

Conditioning mares for milking is efficient (Masloboev, 1961; Dyusembin, 1968). Several factors which modify udder emptying remain unknown. Doreau et al. (1986a) observed that when milking 10 mares at 5 physiological stages, the very high variations in milk obtained during milking when the foal was present cannot be explained by lactation stage or by the individual effect, as might have been assumed. We were not able to relate this quantity to the apparent calm or stress of the mare during milking.

Many authors since Neuhaus (1961) and Linzell (1972) have recommended the use of exogenous oxytocin injections. The problems associated with this method have been widely described when applied to bovines or ovines by Boyazoglu (1963), Le Neindre (1973) and Doney et al. (1979). The quantity of milk consumed by the offspring is generally overestimated by taking into account the residual milk which is high just after foaling. The same may be true for equids. To our knowledge, the choice of the quantity to be injected has not been specifically studied in the mare; $10-25$ IU are often injected in cows (cf., Thompson et al., 1973). Although high amounts do not seem necessary to these authors, the quantity injected in mares may depend on the specificity of this species, in which the lack of references is evident, and on the marked individual variations in reactions to oxytocin injection, as found in ewes (Labussière et al., 1969). In equids, milkings with oxytocin were carried out by Neuhaus (1961) in mares (20 IU, intravenously), Linzell et al. (1972) in ponies (0.5 IU, intravenously), Oftedal et al. (1983) and Boulot (1987) in 500-kg mares (20 IU respectively, intramuscularly and intravenously) and Doreau et al. (1986a) in $800-\mathrm{kg}$ mares (40 IU, intravenously). These concentrations are high and probably non-physiological. This can compensate the higher duration of manual milking when compared to mechanical milking or suckling (Le Du, 1986). None of the authors performed milking with oxytocin when milk yield assessment was the main purpose. The objective was to obtain maximal milk yield for human utilization, to compare with nutrient flow towards the udder, or to obtain a representative sample for analysis. The milking routine differed according the authors. Oftedal et al. (1983) began milking after oxytocin injection; in this condition an incomplete emptying can occur. Linzell et al. (1972) emptied the udder using oxytocin, then allowed milk secretion, then emptied the udder. The milk obtained represents the secretion capacity during a given interval, but slightly differs from the milk sucked by the foal, which does not completely empty 
the udder. Doreau et al. (1986a) used another technique : complete emptying by the foal, then milk secretion during a given interval, then milking with oxytocin. This method also slightly overestimates the milk really sucked. The reliability of the method with oxytocin injection is indicated when it is compared with a body water marker used as a reference (Doreau et al., 1986a). With 30 measurements, the means were the same for both methods, but milking with oxytocin yielded more dispersed and sometimes aberrant data for the same physiological stage. One milking appears insufficient to estimate daily milk yield.

Another method, which is probably more accurate, was used by Nordstrøm (1970). Mares were milked using oxytocin every hour over a period of $24 \mathrm{~h}$. The reliability of the method depends on a possible galactopoietic effect of oxytocin when repeated injections are made (Dyusembin, 1972a). Further research on this technique would be of interest.

\section{Weighing before and after suckling}

This technique has been performed very frequently in equids since the studies performed by Blechschmidt (1933). The foal is removed from the mare's box for a period of $45 \mathrm{~min}$ (Bouwman and Van Der Schee, 1978) to $8 \mathrm{~h}$ (Lukas et al., 1972). The foal is then weighed, allowed to suck, then weighed again. The difference between the 2 weighings gives an estimate of the milk intake. According to the authors, these measurements are repeated over a 24- to 48-h period, or only over a period of 8-12 consecutive hours. Measurements are either diurnal or taken both day and night. This method has several disadvantages. To begin with, it disturbs the mother-offspring relationships and natural nursing behaviour.

When suckings very frequent, immediately after delivery, measurements are at wider intervals than natural suckings. It is not certain that the young foal, which consumes small amounts of milk at each sucking, empties the udder when it is full. Moreover, if successive suckings are too spaced out, the udder's secretory ability may decrease during the interval between suckings. The low udder capacity, seldom more than 2 I (Table I) and its high filling rate, between $1.5-2 \mathrm{~h}$ (Alaguzhin, 1964), may result in an underestimation of milk intake. In order to improve the precision of the method at the onset of lactation, Bouwman and Van Der Schee (1978) chose an interval between bouts of sucking that takes into account behavioural data, and varies between 45 $\mathrm{min}$ at 1 month and $2 \mathrm{~h}$ at 4 months. However, measurements of daily sucking bouts show higher values : 70 after birth, 35 at 1 month and $\approx 25$ at 4 months (Barmincev, 1960; Tyler, 1972; Bouwman and Van Der Schee, 1978; Martin-Rosset et al., 1978). This method is probably less reliable than in other species, such as bovines, when suckling frequency is low. In mares, the high number of weighsuck-weigh sequences increases the risks of error.

Other problems tend to decrease the reliability of this method. If measurements occur only during daylight, the result may be biased because foals suck longer during the day than at night (Duncan et al., 1984). Nevertheless, nocturnal experimentation may disturb animal behaviour. Some analytical inaccuracy persists. It is difficult to weigh foals without error, particularly after they are 2 months old because of the limited accuracy of the scales and foal stress. Estimates of the weights of urine and/or feces have to be made if defecation or urination occurs during suckling. The later the lactation stage, the better this method proves to be. 


\section{Use of markers}

When the offspring receives only milk, intake may be estimated from the water turnover rate and body volume. A body water marker has to be infused intravenously into the offspring (deuterium oxide or tritiated water). The decrease in its concentration is analyzed. Water intake from milk and water excretion (urine, feces, sweat, exhaled steam) would have to be continuous. If, during the few days when measurements are taken, milk intake and body water volume are considered constant, the following relationship can be set up :

$C=Q / V e^{-k / v t}(C:$ marker concentration; $t$ : time; $Q$ : quantity of marker injected; $V$ : body water volume; $k$ : water intake per unit of time).

This equation allows water intake by the offspring to be calculated. If milk dry matter is known, and if metabolic water production from nutrient oxidation is estimated, milk intake can be calculated. This method was first used by Macfarlane et al. (1969) in lambs. Improvements were made by Dove and Freer (1979) in lambs and Doreau and Dussap (1980) in foals by taking into account the liveweight gain of the offspring during measurements, and therefore, the increased body water volume. With this modification the method, which has been tested with bottle-fed lambs by these 2 authors, was very reliable. Measurement error was under $5 \%$ and there was no systematic bias. This method has been used for several years to estimate mare milk production (Doreau and Dussap; 1980; Doreau et al., 1982, Oftedal et al., 1983; Doreau et al., 1986a; Boulot, 1987), as in other species (Oftedal, 1984). Although no standardization has been set up in equids, this method is probably as precise in equines as in ovines because the foal sucks frequently. To our knowledge, this method and weighsuck-weigh method have not been compared in equines. However, using a marker can prove to be useful immediately after foaling, when suck frequency is highest, and when the weigh-suck-weigh method is least feasible. Moreover, this method does not disturb maternal nursing and has none of the analytical complications of the weigh-suck - weigh technique. Its main disadvantage is that it cannot be applied when milk is not the only source of water, i.e. after 2 months. In this case, 2 markers have to be used, one in the mother, the other in the offspring (Holleman et al., 1975; Wright and Wolff, 1976). Because of its complexity, this method has not yet been used in equids.

A completely different method of marking milk in the udder has been used in suckled cows by $\mathrm{Nicol}$ and Irvine (1973). One isotope of iodine is given in a known amount to the offspring; the other is introduced in a known amount in the udder. The ratio of the 2 isotopes in the calf blood allows milk intake during one suck to be calculated. This method can be used at pasture. However, this method is limited because it disturbs the motheroffspring relationship. Extrapolation of the milk intake during a suck to daily intake is difficult, especially as suck frequency is high.

\section{Methods of estimating milk compo- sition}

As early as 1937, Linton indicated the possible bias in milk composition data due to a bad sampling. Differences in analytical methods may also occur. This chapter will successively deal with these 2 problems. 


\section{Sampling methods}

As in other species, mare milk composition is not constant during milking. The only constituent in which concentration varies in a significant way is fat. In some individual cases, milk fat content at the onset of milking may be below $1 \mathrm{~g} / \mathrm{kg}$ (Doreau et al., 1986a). This might explain some zero milk fat contents which have been reported in the literature (Neuhaus, 1959). Fat content may be 2 or 3 times higher at the end of the milking than at the beginning (Table II). The data of Doreau et al. (1986a) show that the increase in milk fat during milking becomes higher after an oxytocin injection. The possible effect of oxytocin on milk fat has also been reported by Smolders et al. (1989). According to Labussière (1984), the oxytocin release, through compression of acini, should cut the fat globule aggregates and allow their crossing towards the cistern. So, every milking process which involves an insufficient oxytocin release will give a low milk volume of low-fat milk. It is better to obtain the whole content of one side or, if

Table II. Variations in mare milk fat content (\%) throughout milking.

\begin{tabular}{|c|c|c|c|c|c|}
\hline Authors & $\begin{array}{l}\text { No. of } \\
\text { observations }\end{array}$ & $\begin{array}{l}\text { Beginning of } \\
\text { milking }\end{array}$ & $\begin{array}{l}\text { End of } \\
\text { milking }\end{array}$ & Mean & \\
\hline $\begin{array}{l}\text { Prowosnik (1931) } \\
\text { (N) }\end{array}$ & $\begin{array}{l}1 \\
1 \\
1\end{array}$ & $\begin{array}{l}0.2 \\
0.1 \\
0.4\end{array}$ & $\begin{array}{l}0.85 \\
2.23 \\
1.45\end{array}$ & $\begin{array}{l}0.23 \\
1.87 \\
1.13\end{array}$ & \\
\hline $\begin{array}{l}\text { Dittrich (1938) } \\
\text { (N) }\end{array}$ & $\begin{array}{l}1 \\
1 \\
1 \\
1\end{array}$ & $\begin{array}{l}0.1 \\
1.83 \\
0.29 \\
0.19\end{array}$ & $\begin{array}{l}1.18 \\
0.76 \\
5.55 \\
2.15\end{array}$ & & \\
\hline \multirow[t]{2}{*}{$\begin{array}{l}\text { Dyusembin (1972b) } \\
\text { (D) }\end{array}$} & 3 & 0.45 & 0.82 & 0.63 & \\
\hline & & $\begin{array}{l}\text { Cisternal } \\
\text { milk }\end{array}$ & $\begin{array}{l}\text { Alveolar } \\
\text { milk }\end{array}$ & $\begin{array}{l}\text { Stripping } \\
\text { milk }\end{array}$ & $\begin{array}{l}\text { Residual } \\
\text { milk }\end{array}$ \\
\hline \multirow[t]{2}{*}{$\begin{array}{l}\text { Cherepanova and } \\
\text { Belokobylenko (1974) } \\
\text { (D) }\end{array}$} & & 0.15 & $0.5-1.1$ & $1.1-1.4$ & $3.5-7.2$ \\
\hline & & $\begin{array}{l}\text { Beginning of } \\
\text { milking }\end{array}$ & $\begin{array}{l}\text { Last fraction } \\
\text { before oxytocin }\end{array}$ & $\begin{array}{l}\text { First fraction } \\
n \text { after oxytocin }\end{array}$ & $\begin{array}{l}\text { End of } \\
\text { milking }\end{array}$ \\
\hline $\begin{array}{l}\text { Doreau et al. (1986a) } \\
\text { (N) }\end{array}$ & 50 & 0.98 & 1.05 & 1.29 & 1.78 \\
\hline
\end{tabular}

$N$ : nursing mares. $D$ : dairy mares. 
possible, the two sides of the udder so as to take into account a possible difference in milk composition between the two sides. Prowosnik (1931), Dittrich (1938) and Doreau et al. (1986a) observed at a mean no difference in milk composition between the two sides, but with individual data, milk fat was higher on one side when the obtained milk volume was lower than on the other side.

Protein and lactose contents have been found to be slightly and nonsignificantly lower at the end of milking than at the beginning (respectively 1.2 and $0.5 \mathrm{~g} / \mathrm{kg}$; Doreau et al., 1986a). This difference, already observed in other species (Labussière, 1984), can be in part $(0.2 \mathrm{~g} / \mathrm{kg})$ explained by a passive variation caused by the increase in fat content. A different result (increase in protein and no variation in lactose content) was found by Dyusembin (1972b) using a small number of mares.

The use of oxytocin injection, which promotes udder emptying, may have a short-term effect on milk composition. According to Wheelock et al. (1965), when a cow udder is emptied after an oxytocin injection, sodium, chloride and whey protein rise and lactose falls in the following milking. When several mare milk samples are not obtained successively, oxytocin injection probably has no effect on milk composition. In most cases, literature data come from spot samplings.

In order to obtain the amount of milk corresponding exactly to a suckling of the offspring, numerous authors separate mare and foal before milking (Table III). This time of separation must not be overestimated because milk stasis in the udder is followed by an increase in fat, protein and minerals and a decrease in lactose content, either for the current or for the subsequent milking (Petersen and Rigor, quoted by Linton, 1937 in mares and Labussière and Coindet, 1968, in cows). The most accurate solution is probably to calculate the time of separation using the natural interval between 2 suckings. An attempt was made by Doreau et al. (1986a) who applied the intervals previously found by Martin-Rosset et al. (1978). The long separation times between mare and foal in the experiments of Gibbs et al. (1982) and Smoczynski and Tomczynski (1982) (respectively 3 and 6 hours) may have influenced milk composition.

\section{Methods of milk analysis}

Fat. Most authors use the Rose-Gottlieb reference method or a derived method (Ullirey et al., 1966; Johnston et al., 1970; Oftedal et al., 1983; Pagan and Hintz, 1986) or the volumetric method of Gerber (Linton, 1937; Kulisa, 1977; Smoczynski and Tomczynski, 1982). In these two methods, the result does not depend on milk fat composition. Rapid methods such as turbidimetric analysis (Gibbs et al., 1982) or infrared spectrophotometry (Zimmerman, 1985) should be calibrated for each animal species. Indeed, the fat refractive index depends on each species (Grappin and Jeunet, 1979). Conditions for a good calibration were defined by Smolders et al. (1989). In mother's milk, an excellent correlation between infrared spectrophotometry and Rose-Gottlieb method was found by Hundrieser et al. (1984). Dorea et al. (1981), however, found low relationships in mother's milk. The only comparison in mares (Doreau et al., 1985) showed close relationships between Rose-Gottlieb, Gerber, turbidimetric and spectrophotometric methods, but resulted in the need for a specific spectrophotometric calibration in mare's milk.

Protein. Most authors have analyzed crude protein in mare milk by the Kjeldahl 
Table III. Methods of mare milk sampling for composition analysis; outline of the literature.

Authors

Methods of sampling

Amounts of milk obtained

$(\mathrm{ml})$

Linton (1937)

Neseni et al. (1958)

Ulirey et al. (1966)

Johnston et al. (1970)

Zimmerman (1985)

Linzell et al. (1972)

Ashcraft and Tyznik (1976) Mare-foal separation : 1 h. Manual

milking of one side while the other

is sucked

Bouwman and

Van Der Schee (1978)

Gibbs et al. (1982)

Smoczynski and

Tomczynski (1982)

Oftedal et al. (1983)

Miraglia et al. (1986)

Doreau et al. (1986a)

Boulot (1987)

Mare-foal separation : $2 \mathrm{~h}$

Manual milking of the 2 sides

1 sampling by manual milking before

and after foal suck, both sides

of one side while the other is sucked

Mare - foal separation : $30 \mathrm{~min}$

Manual milking of one side while

the other is sucked

Manual milking of one side while the

other is sucked, every hour, with an

oxytocin injection

Mare-foal separation : $30-45 \mathrm{~min}$

of one side while the other is sucked

Mare-foal separation : $3 \mathrm{~h}$

Manual milking of one side while

the other is sucked

Mare-foal separation : $6 \mathrm{~h}$

Manual milking while foal is present

Mare-foal separation : $1-2 \mathrm{~h}$

Manual milking of one side while the

Mare-foal separation : $1 \mathrm{~h}$

Manual milking of one side while

the other is sucked
No mare-foal separation. Manual milking

$110-170$

(Johnston et al.)

according to lactation stage. Manual milking

200

$>300$

other is sucked, with an oxytocin injection

$500 \pm 177$

Mare-foal separation : $30-90$ min according

to lactation stage. Manual milking of the

$964 \pm 439$ both sides while foal is present, with an oxytocin injection 
method. Dye-binding protein method (Gibbs et al., 1982) and infrared spectrophotometry (Zimmerman, 1985) have seldom been used. Regarding fat, the utilization of infrared spectophotometry requires a specific calibration for mare milk (Doreau et al., 1985). According to these authors, a dye-binding protein method (amido black calibrated on the Kjeldahl method with cow milk) gave higher results than Kjeldahl (29.6 vs 25.8 $\mathrm{g} / \mathrm{kg}$ ) although the milk studied contained $7-13 \%$ non-protein nitrogen. This difference can be explained by the higher capacity of indicator binding to whey protein (Grappin and Jeunet, 1979) which form $\approx 50 \%$ of mare milk, or to the specificity of some proteins in mare milk.

Lactose. Lactose is analyzed by very different techniques : Bertrand method (reduction then titration : Kulisa, 1977; Smoczynski and Tomczynski, 1982), phenol-sulphuric acid colorimetric method (Oftedal et al., 1983), enzymatic method (Pagan and Hintz, 1986) or infrared spectrophotometry (Zimmerman, 1985; Doreau et al., 1986a). With this latter technique, a specific calibration for mare milk does not seem necessary, as lactose is the same chemical entity for all species. The most accurate method is probably the gas-chromatographic technique (Kulisa, 1980) which analyses both lactose and other sugars. These different methods were not compared for mare milk; it might be that some of the differences in lactose content observed from one trial to another is explained by the particular analysis technique utilized. Another source of difference is the expression of lactose concentration, as anhydrous or monohydrate, which is not always noticed in the literature.

Numerous authors have given lactose concentrations by estimating the difference between dry matter and fat, protein and ash. This method evidently involves error and uncertainties regarding these components.

\section{Conclusion}

The complexity of the methods for estimating mare milk yield has probably been a reason for the small number of experiments. It is possible that recent method improvements may contribute towards promoting these studies. Despite the lack of direct comparisons between methods, it is considered that the use of markers is the most accurate method in early lactation. The weigh-suck-weigh technique, although sometimes lacking in precision, can be applied in mid-lactation.

Measurements of mare milk composition are more numerous. However, some methodological problems noted in this review lead us to question the reliability of some results. The main problem remains the estimation of fat content, which requires very careful sampling.

\section{References}

Alaguzhin A. (1964) Milk productivity of Lokai mares. Konevodstvo Konnyi Sport 34, 13-14 (in Russian)

Ashcraft A. \& Tyznik W.J. (1976) Effect of diet on volume and composition in mare's milk. $J$. Anim. Sci. 43, 248 (abstr.)

Barmincev J.N. (1960) Breeding horses for milk under conditions in Kazakhstan. Trudy l-i Konf. Mol. Konevod. Kumysod. Mosk. 20-25 (Anim. Breed. Abstr. (1961) 29, 397) (in Russian)

Barone R. \& Monnet C. (1955) Les mamelles des équidés domestiques. Bull. Soc. Sci. Vét. Lyon 57, 73-92

Bilek J., Dusek J. \& Lechner F. (1955) New findings on methods of obtaining mares' milk 
and the influence on its secretion. Sborn. Csl. Akad. Zemed. Ved. 28, 859-886 (in Czech)

Blechschmidt H. (1933) Experimentaluntersuchungen und Ermittlungen über die Ernährung des Pferdes auf der Weide. Landw. Jb. $77,463-560$

Boulot S. (1987) L'ingestion chez la jument. Etude de quelques facteurs de variation au cours du cycle gestation-lactation. Implications nutritionnelles et métaboliques. Thèse Doct. Ing.. ENSA Rennes, Univ. Rennes I

Bouwman H. \& Van Der Schee W. (1978) Composition and production of milk from Dutch warmblooded saddle horse mares. $Z$. Tierphysiol. Tierernährg. Futtermittelk. 40, 3953

Boyazoglu J.G. (1963) Aspects quantitatifs de la production laitière des brebis. Ann. Zootech. 12, 237-296

Cherepanova V. (1979) Dairy horses farming in Kazakhstan. Konevodstvo Konnyi Sport 8, 5-6 (in Russian)

Cherepanova V.P. \& Belokobylenko V.T. (1974) Milk ejection characteristics in machine milking of mares. Proc. 3rd All-Union Symp. Physiol. Principles Machine milking, Borovsk (Dairy Sci. Abstr. (1975) 37, 691) (in Russian)

Dittrich H. (1938) Untersuchungen über die Zusammensetzung von Pferdemilch. Milchwirtschäftl. Forsch. 19, 406-412

Doney J.M., Peart J.N., Smith W.F. \& Louda F. (1979) A consideration of techniques for estimating of milk yield by suckled sheep and a comparison of estimates obtained by two methods in relation to the effect of breed, level of production and stage of lactation. J. Agric. Sci. Camb. 92, 123-132

Dorea J.G., Horner M.R., Bezerra V.L. \& Borgo L.A. (1981) Comparison of two methods for determining protein and lipid in human colostrum and mature milk. Nutr. Rep. Int. 24, 985-991

Doreau M. \& Boulot S. (1989) Recent knowledge on mare milk production : a review. Livest. Proc. Sci. 21, in press

Doreau M., Boulot S., Jeunet R. \& Trin J.M. (1985) Comparaison de différentes méthodes de dosage des matières grasses et des matières azotées du lait de jument. Lait 65 , 149-161

Doreau M., Boulot S., Martin-Rosset W. \& Dubroeucq $H$. (1986a) Milking lactating mares using oxytocin : milk volume and composition. Reprod. Nutr. Dev. 26, 1-11
Doreau M., Boulot S., Martin-Rosset W. \& Robelin J. (1986b) Relationship between nutrient intake, growth and body composition of the nursing foal. Reprod. Nutr. Dev. 26, 683690

Doreau M. \& Dussap G. (1980) Estimation de la production laitière de la jument allaitante par marquage de l'eau corporelle du poulain. Reprod. Nutr. Dev. 20, 1883-1892

Doreau M., Martin-Rosset W. \& Dubroeucq H. (1982) Production laitière de la jument. Liaison avec la croissance du poulain. C.R. $8^{\ominus}$ Journée d'Etude du CEREOPA, CEREOPA, Paris, pp. $88-100$

Dove M. \& Freer M. (1979) The accuracy of tritiated water turnover rate as an estimate of milk intake in lambs. Aust. J. Agric. Res. 30, 725-739

Duncan P., Harvey P.H. \& Wells S.M. (1984) On lactation and associated behaviour in natural herd of horses. Anim. Behav. 32, 255263

Dyusembin K. (1966) Milk-ejection reflex in mares milked with the modified milking machine "Temp». Trudy Inst. Fiziol. Alma-Ata $10,148-152$ (in Russian)

Dyusembin K. (1968) Specific traits of the milk ejection reflex in mares. Trudy Inst. Fiziol. Alma-Ata 12, 155-159 (in Russian)

Dyusembin K. (1972a) The role of oxytocin in regulating lactation in mares. Trudy Inst. Fiziol. Alma-Ata 17, 37-41 (in Russian)

Dyusembin K. (1972b) Uneven distribution of major milk components in consecutive portions of a milking in farm animals. Trudy Inst. Fiziol. Alma-Ata 17, $42-45$ (in Russian)

Fedotov P.A. \& Duisembaev K. (1974) Morphological characteristics of mare's udders. Genet. Selekt. Rast. Zhiv. Kazakh. 265-266 (in Russian) (Dairy Sci. Abstr. (1977) 39, 250)

Gibbs P.D., Potter G.D., Blake R.W. \& Mc Mullan W.C. (1982) Milk production of quarter horse mares during 150 days of lactation. $J$. Anim. Sci. 54, 496-499

Grappin R. \& Jeunet R. (1979) Méthodes de routine pour le dosage de la matière grasse et des protéines du lait de chèvre. Lait 59 , 345360

Holleman D.F., White R.G. \& Luick J.R. (1975) New isotope methods for estimating milk intake and yield. J. Dairy Sci. 58, 1814-1821

Hundrieser K.E., Clark R.M., Jensen R.G. \& Ferris A.M. (1984) A comparison of methods 
for determination of total lipids in human milk. Nutr. Res. 4, 21-26

Johnston R.H., Kamstra L.D. \& Kohler P.H. (1970) Mare's milk composition as related to foal heat scours. J. Anim. Sci. 31, 549-553

Kuanyshbekova G.A. (1975) Oxytocic activity of blood in lactating mares. Trudy Inst. Fiziol. Alma-Ata Kazakhs. SSR 21, 128-131 (in Russian)

Kulisa M. (1977) The composition of mare milk in three horse breeds with reference to $\mathrm{N}$ acetylneuraminic acid. Acta Agrar. Sylv. Ser. Zootech. 17, 25-37 (in Polish)

Kulisa M. (1980) Lactose, free glucose and galactose levels in the milk of Arab mares. Rocz. Nauk. Zootech. 7, 31-36 (in Polish)

Labussière J. (1984) Influence des techniques de traite sur la composition du lait de quelques espèces domestiques. C.R. Symp. La composition chimique du lait et ses incidences technologiques, INRA Rennes, pp. 20

Labussière J. \& Coindet J. (1968) Effets de la suppression de la traite du dimanche soir, chez les bovins de race française frisonne pie noire. Ann. Zootech. 17, 231-244

Labussière J., Martinet J. \& Denamur R. (1969) The influence of milk ejection reflex on the flow rate during milking of ewes. J. Dairy Res. 36, 191-201

Le Du J. (1986) Mechanical milking of mares. Proc. 37th Ann. Meet. EAAP, Budapest, pp. 12

Le Neindre P. (1973) Observations sur l'estimation de la production laitière des vaches allaitantes par la pesée du veau avant et après la tétée. Ann. Zootech. 22, 413-422

Le Neindre P., Petit M. \& Muller A. (1976) Production laitière des vaches normandes à la traite ou à l'allaitement. Ann. Zootech. 25, 533542

Leonhard I. (1956) Preliminary investigations on the production and chemical composition of mare's milk. Rocz. Nauk Roln. 70 B3, 333-346 (in Polish)

Linton R.G. (1937) The composition of mare's milk. J. Dairy Sci. 8, 143-172

Linzell J.L. (1972) Milk yield, energy loss in milk and mammary gland weight in different species. Dairy Sci. Abstr. 34, 351-360

Linzell J.L., Annison F., Bickerstaffe R. \& Jeffcott L.B. (1972) Mammary and whole-body metabolism of glucose, acetate, palmitate in the lactating horse. Proc. Nutr. Soc. 31, 72-73
Lukas V.K., Albert W.W., Owens F.N. \& Peters A. (1972) Lactation of Shetland mares. $J$. Anim. Sci. 34, 350 (abstr.)

Macfarlane W.V., Howard B. \& Siebert B.D. (1969) Tritiated water in the measurement of milk intake and tissue growth of ruminants in the field. Nature 221, 578-579

Martin-Rosset W., Doreau M. \& Cloix J. (1978) Etude des activités d'un troupeau de poulinières de trait et de leurs poulains au pâturage. Ann. Zootech. 27, 33-45

Masloboev A.J. (1961) Characteristics of lactation in mares. Trudy Vses. Inst. Konevodstva. 23, 135-150 (in Russian) (Nutr. Abstr. Rev. (1962) 32, 574-575)

Miraglia N., Quintavalla F., Mariani P. \& Catalano A.L. (1986) Plasma biochemistry changes in mares and foals in relation to nutritional aspects. Preliminary trials. Proc. 37th Ann. Meet. Europ. Ass. Anim. Prod., pp. 11

Neseni R., Flade E., Heidler G. \& Steger H. (1958) Milchleistung und Milchzusammensetzung von Stuten im Verlaufe der Laktation. Arch. Tierzucht. 1, 91-129

Neuhaus U. (1959) Milch und Milchgewinnung von Pferdestuten. Z. Tierzucht. 73, 370-392

Neuhaus U. (1961) Obtaining mare's milk for the feeding of human infants. VIIlth Int. Congr. Anim. Prod. (Hamburg), II, 184-185

Nicol A.M. \& Irvine C.H.G. (1973) Measurement of the milk consumption of suckling beef calves by an isotope dilution method. Proc. N.Z. Soc. Anim. Prod. 33, 176-183

Nordstrem A. (1970) On the growth of young horses and on factors affecting the growth. Mast. Thesis, Univ. Helsinki (in Finnish)

Oftedal O.T. (1984) Milk composition, milk yield and energy ouptput at peak lactation : a comparative review. Symp. Zool. Soc. Lond. 51, 33-85

Oftedal O.T., Hintz H.F. \& Schryver H.F. (1983) Lactation in the horse : milk composition and intake by foals. J. Nutr. 113, 2196-2206

Pagan J.D. \& Hintz H.F. (1986) Composition of milk from pony mares fed various levels of digestible energy. Cornell Vet. 76, 139-148

Prowosnik L. (1931) Neue Untersuchungen über die Zusammensetzung der Pferdemilch. Z. Züchtgskde 6, 329-338

Ricordeau G. \& Denamur R. (1962) Production laitière des brebis Préalpes du sud pendant les 
phases d'allaitement, de sevrage et de traite. Ann. Zootech. 11, 5-38

Sharma O.P. (1974) Release of oxytocin elicited by suckling stimulus in mares. $J$. Reprod. Fert. 37, 421-423

Smoczynski S. \& Tomczynski R. (1982) A study of chemical composition of mare milk. I. Chemical composition of mare milk in first ten days of lactation. Zesz. Nauk. Akad. Roln.Tech. Olszt. 17, 77-83 (in Polish)

Smolders E.A.A. (1989) Composition of horse milk during the suckling period. Livest. Prod. Sci. (in press)

Storch R. (1969) Uber das maschinelle Melken von Stuten. Milchwissenschaft 24, 145-146

Tarasevich L.F. (1979) The relationship of milk production of White-Russian Coach mares with udder shape and measurements. Sbornik Trudov. Bieloruskii Nauchno-Issledovatel'skii Inst. Zhivotnovodstva 20, 110-114 (in Russian) (Anim. Breed. Abstr. (1980) 48, 512)

Thompson P.D., Paape M.J. \& Smith J.W. (1973) Residual milk as affected by dose and time of injection of oxytocin. J. Dairy Res. 40, 221-227
Tumanova E.B. (1966) Certain problems of the morphological physiology of the udder of the mare. Zap. Leningr. Sel.'-Khoz. Inst. 102, 130134 (in Russian) (Dairy Sci. Abstr. (1967) 29, 501-502)

Tyler S. (1972) The behaviour and social organisation of the New Forest ponies. Anim. Behav. Monogr. 5, 85-196

Ullirey D.E., Struthers R.D., Hendricks D.G. \& Brent B.E. (1966) Composition of mare's milk. J. Anim. Sci. 25, 217-221

Wheelock J.V., Rook J.A.F. \& Dodd F.H. (1965) The effect of intravenous injections of oxytocin during milking and the removal of residual milk on the composition of cow's milk. J. Dairy Res. 32, 255-262

Wright D.E. \& Wolff J.E. (1976) Measuring milk intake of lambs suckling grazing ewes by a double isotope method. Proc. N.Z. Soc. Anim. Prod. 36, 99-102

Zimmerman R.A. (1985) Effect of ration on composition of mare's milk. Proc. 9th Eq. Nutr. Physiol. Symp. 96-102 